Interestingly, several conventions, all drafted in the wake of the CISG, have sought to address the conflicts-of-law issue. ${ }^{5}$ None has attracted much support, and none is in effect. What should one make of the international community's apparent failure to deal directly with the root source of legal instability in international sales contracts?

Several rejoinders are possible. First, the trend toward arbitration may obviate the need for an international consensus on choice of law. Arbitrators have their own reasons to reduce the legal risk associated with the disputes they consider: If they develop a reputation for reaching outcomes that contracting parties don't want, they won't get hired. Second, many of the parties to an international sales contract that do not negotiate a choice-of-law or choiceof-forum clause, or who might be sued in a forum where such clauses are unenforceable, may find this risk acceptable. In most cases, a forum state will apply its own law, which means the legal risk is closely tied to the location of attachable assets. If a party has assets only in its home jurisdiction, then as a practical matter it will find itself exposed only to that jurisdiction's contracts law. Multinational firms with assets in multiple jurisdictions presumably can respond to their specific risk by bargaining for choice-of-forum or choiceof-law clauses. If these conjectures bear some relation to reality, then the commercial community may not have any great reason to pressure governments for international regulation of choice of law.

Law reform, whether international or domestic, is a passion of a certain kind of legal academic. As thought experiments and the basis for a research agenda, these projects can be invaluable. But, as our experience with the CISG illustrates, the execution of law reform may do more harm than good.

\title{
Buyer's Remedies in the Case of Non-Conforming Goods: Some Problems in a Core Area of the CISG
}

\author{
By Ingeborg Schwenzer
}

\section{INTRODUCTION}

Non-conformity of the goods and the buyer's respective remedies constitute the core of any law of sales. More than 50 percent of all cases that have been litigated and decided under the CISG at this stage have involved questions surrounding these issues. The CISG has set up a consistent scheme for determining non-conformity and the remedies that the buyer can resort to in the case of non-conformity. I would dare say that this system is superior to any domestic sales law that I know, including both traditional civil-law systems such as Germany, Switzerland, and France, as well as common-law systems such as England and the United States. This statement not only holds true with respect to the prerequisites for non-conformity but also with respect to the consequences of non-conformity of the goods. However, uniformity in this core area of international sales law, which has been arduously achieved, risks being endangered by domestic preconceived views of judges and arbitrators.

I would like briefly to explore two fields in which uniformity has been jeopardized during recent application of the CISG. The first might be regarded as an intrinsic problem of

\footnotetext{
${ }^{5}$ The Hague Conference on Private International Law has produced the Convention on the Law Applicable to Contracts for the International Sale of Goods, Dec. 22, 1986, and the Convention on Choice of Court Agreements, Jun. 30, 2005. None is in force.

" Professor of Private Law, University of Basel, Switzerland. The author would like to express her gratitude to her research assistant, Olivier Mosimann, for his assistance in preparing these remarks.
} 
interpretation of the CISG provisions itself, namely the buyer's duty to inspect the goods and to notify the seller of any non-conformity. The second one is a kind of extrinsic problem, namely the possibility of the buyer to turn to concurring domestic remedies, for example, if for some reason CISG remedies are excluded.

Let me first turn to the buyer's duty to inspect and notify.

\section{The Buyer's Duty to InSPECT AND Notify}

This duty is laid down in Articles 38 and 39 of the CISG. The problem inherent in the interpretation of these articles is the divergence of domestic sales laws concerning the duty of the buyer to inspect the goods and give notice of any non-conformity. ${ }^{1}$ Most domestic sales laws do not recognize any such obligation of the buyer at all. ${ }^{2}$ Even in those countries whose domestic sales laws do contain such provisions, their function and interpretation varies greatly. While Germanic legal systems require notice to be given without undue delay, ${ }^{3}$ or even immediately, ${ }^{4}$ under Anglo-American ${ }^{5}$ and Dutch $^{6}$ law, it is sufficient for it to be given within a reasonable time or within an appropriate period after the actual discovery or possibility of discovering the defect. Thus, in practice, the outcomes when applying these differing interpretations of the notice period vary considerably. Under the domestic laws in Germanspeaking countries, failure to comply with the duty to give notice is apparently the strongest weapon used by sellers to defeat any claims by the buyer based on a lack of conformity of the goods. Courts can require notice to be given by the buyer within as short a period as three to five working days. ${ }^{7}$ In contrast to the Germanic approach, U.S. courts generally hold the purpose of the duty to give notice to be the prevention of fraud by a dilly-dallying buyer. $^{8}$ Thus, more often than not, a period of more than one month is still held to be reasonable. ${ }^{9}$ It was against this diverse background that the inclusion of this obligation of the buyer was one of the most highly debated issues when drafting the CISG. ${ }^{10}$ To sum up the drafting history, the CISG provisions on examination and notice may be fairly characterized as being closer to those legal systems that provide for a duty to give notice within a reasonable

\footnotetext{
${ }^{1}$ See CISG Advisory Council, Op. No. 2, Examination of the Goods and Notice of Non-Conformity - ARTICLES 38, 39, June 7, 2004, ERIC BERGSTEN (Rapporteur), paras. 2.1.-2.4, available at $<$ http://www.cisg-online.ch/ cisg/docs/CISG-AC_Op_no_2.pdf >.

${ }^{2}$ Cf., e.g., France and Belgium: Art. 1648 Code civil [Cc-Civil Code].

${ }^{3}$ See $\S \$ 377,378$ German and Austrian Handelsgesetzbuch [HGB-Commercial Code].

${ }^{4}$ See Art. 201 Swiss Obligationenrecht [OR-Code of Obligations].

${ }^{5}$ See §2-607(3)(a) UCC; see also §§2-607(3)(a) UCC 2003, 35(1) SGA 1979.

${ }^{6}$ See Art. 7:23.1 Burgerlijk Wetboek [BW-Civil Code].

${ }^{7}$ Cf. for Austria $\$ \$ 377,378$ Austrian HGB; Emst A. Kramer, $\$ \$ 377,378$, para. 41, in Kommentar zum HANDELSGESETZBUCH MIT EINSCHLÄGIGEN RECHTSVORSCHRIFTEN (Manfred Straube ed., 2003); for Germany \$377

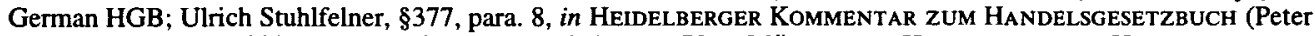
Glanegger et al. eds., 2007); Barbara Grunewald, \$377, para. 72, in MÜNCHENER KOMMENTAR ZUM HANDELSGESETZBUCH (Karsten Schmidt ed., 2004); for Switzerland Art. 201 Swiss OR; Herbert Schönle \& Peter Higi, Art. 201, para. 29a, in Zürcher Kommentar (Peter Gauch ed., 2005); Hans Giger, Art. 201, para. 81, in BerNer Komment AR (Arthur Meier-Hayoz ed., 1979).

${ }^{8}$ Cf. J J Ames J. White \& Robert S. Summers, Uniform Commercial Code 419 (5th ed., 2000) (citing A.C. Carpenter, Inc. v. Boyer Potato Chips, 28 Agric. Dec. 1557 (1969), 1969 WL 10993); G. \& D. Poultry Farms, Inc. v. Long Island Butter \& Egg Co., Sup. Ct. NY, Nov. 3, 1969, 33 A.D.2d 685, 306 N.Y.S.2d 243.

${ }^{9}$ Cf. Opp v. Nieuwsma, Sup. Ct. SD, July 3, 1990, 458 N.W.2d 352, 1990 S.D. LEXIS 87 (four months); Hudson v. Gaines, Ct. App. GA, Feb. 27, 1991, 199 Ga.App. 70, 1991 Ga. App. LEXIS 378 (eight months); Sun Hill Indus., Inc. v. Kraftsman Group, Inc., App. Ct. CT, June 2, 1992, 27 Conn. App. 688, 1992 Conn. App. LEXIS 220 (two months).

${ }^{10}$ Harry M. Flechtner, Buyer's Obligation to Give Notice of Lack of Conformity (Articles 38, 39, 40 and 44), in The Draft UNCITRAL Digest and Beyond: Cases, ANalysis and UnResolved Issues in the UN Sales Convention 378 (Ronald A. Brand et al. eds., 2004) [hereinafter Digest and Beyond].
} 
time in their domestic laws than to those that do not stipulate any notice requirement at all, or to those with very strict notice periods. ${ }^{11}$

However, it does not come as a big surprise that national preconceptions have heavily influenced the interpretation of the CISG provisions concerned. As could be expected, during the first years after the CISG came into force, most of the case law emanated from those countries that had already implemented the forerunner of the CISG, the Uniform Law on the International Sale of Goods (ULIS). In the first German decision concerning Article 39, the court held that giving notice of a defect concerning shoes 16 days after delivery was not within a reasonable time. ${ }^{12}$ Similarly, periods of between 25 days and six weeks were not regarded as reasonable in cases concerning clothes and textiles; ${ }^{13}$ seven days was regarded as too long in the case of gherkins. ${ }^{14}$ One court expressly stated that in the case of textiles, it would consider one week for examination and one week for giving notice as reasonable. ${ }^{15}$

In 1995, against this background and with the situation in other legal systems in mind, I suggested that, for durable goods and in the absence of any special circumstances, one should accept one month as a rough average period for timely notice. ${ }^{16}$ Only shortly after publication of this opinion, the German Bundesgerichtshof, the Supreme Court, for the first time, referred to the one-month period in the well-known "mussels case." ${ }^{17}$ In 1999 the Bundesgerichtshof explicitly ruled in favor of a four-week period starting at the time the buyer knew or ought to have been aware of the lack of conformity of the goods. The court described the fourweek period for giving notice as "regelmässig, i.e., "regular" or "normal." Since then, the supreme court of Switzerland, the Bundesgericht, has followed this line of interpretation by expressly upholding a finding of the lower court that allowed the buyer one week for examination, followed by one month for giving notice, in the case of a defective secondhand textile cleaning machine. ${ }^{18}$

In contrast, the Austrian Supreme Court still stubbornly adopts an approach that is still predominantly influenced by domestic law, by applying an overall period of 14 days for examination and notice. ${ }^{19}$

Thus, there is a real divide within the German-speaking countries, not only with respect to the holdings of the respective supreme courts, but also with respect to scholarly writing. The "noble month," which is favored by the German Bundesgerichtshof as well as the Swiss Bundesgericht, is backed by scholars who are comparatists and who are particularly acquainted with the Anglo-American legal mentality. ${ }^{20}$ In contrast, the Austrian Oberster Gerichtshof's

\footnotetext{
${ }^{11} \mathrm{Cf}$. CISG-AC Op. No. 2, supra note 1, para. 4.4.

${ }^{12}$ Landgericht Stuttgart, Aug. 31, 1989, CISG-online 11.

${ }^{13}$ Cf. Landgericht Stuttgart, Aug. 13, 1991, CISG-online 33; Landgericht Mönchengladbach, May 22, 1992, CISG-online 56; Oberlandesgericht Düsseldorf, Mar. 12, 1993, CISG-online 82; see also Tribunale civile di Cuneo, Jan. 31, 1996, CISG-online 268 (clothes: 23 days after delivery too long).

${ }^{14}$ Cf. Oberlandesgericht Düsseldorf, Jan. 8, 1993, CISG-online 76.

${ }^{15}$ See Landgericht Mönchengladbach, May 22, 1992, CISG-online 56.

${ }^{16}$ See Ingeborg Schwenzer, Art. 39, para. 7, in Kommentar ZUM EINHEITLICHEN UN-KAufrecht-CISG(Ernst v. Caemmerer \& Peter Schlechtriem eds., 2d (German) ed. 1995).

${ }^{17}$ Bundesgerichtshof, Mar. 8, 1995, CISG-online 144.

${ }^{18} \mathrm{Cf}$. Bundesgericht, Nov. 13, 2003, CISG-online 840 .

${ }^{19}$ Cf. Oberster Gerichtshof, Oct. 15, 1998, CISG-online 380; Oberster Gerichtshof, Aug. 27, 1999, CISG-online 485; Oberster Gerichtshof, Jan. 14, 2002, CISG-online 643.

${ }^{20}$ Cf. Daniel Girsberger, Outline for Discussion-Art. 39, 43 and Statutes of Limitation, 25 Years United Nations Convention on Contracts for the International Sale of Goods (CISG), Vienna, March 15-16, 2005, 25 J.L. \& CoM. 2006; David Rüetschi, Substanziierung der Mängelrüge: Bundesgericht, I. Zivilabteilung, Urteil 4 C.395/2001 vom 28. Mai, RECHT, 115, 120-21 (2003).
} 
overall 14-day period is shared by authors ${ }^{21}$ whose approach to this issue is deeply rooted in the intricacies of traditional German sales law and its acceptance in Austria and Switzerland, who try to interpret uniform law rules as closely as possible to their domestic forerunners.

The German-speaking countries aside, most other countries have considerably fewer cases dealing with Articles 38 and 39. Still, a common interpretation can easily be discerned. Throughout the non-German-speaking continental European countries, there are hardly any cases that deny the reasonableness of notice given within one month. Instead, there is ample case law holding that a period for giving notice of more than one month is still reasonable; ${ }^{22}$ the longest period currently accepted by the courts is two months after discovery of the nonconformity and three months after delivery, in this case, of frozen fish. ${ }^{23}$

Until now, there has only been sparse Anglo-American case law interpreting Articles 38 and 39. This phenomenon might be connected to the fact that-in contrast to their Germanic colleagues-Anglo-American sellers are not yet used to immediately raising the objection of the buyer's failure to give notice, as such tactics rarely succeed under domestic law. Where courts and tribunals have had to decide on the issue of timely notice, however, their interpretation of what constitutes a reasonable time has been rather generous. Thus, in the recent TeeVee Toons case decided by the U.S. District Court for the Southern District of New York in August 2006, two months for giving notice were held as reasonable, without further discussion being devoted to this issue. ${ }^{24}$

Let me now turn to the second issue, the question of concurring remedies.

\section{CONCURRING REMEDiES}

The CISG is exclusively concerned with the contractual relationship between the seller and the buyer. However, under most legal systems, the mere existence of contractual remedies does not preclude the buyer from relying on other remedies, particularly those based in tort, if the respective prerequisites are fulfilled. The crucial question then arises of whether a buyer under a CISG sales contract can assert concurring remedies under domestic law, notwithstanding that they may result in outcomes contrary to those reached under the CISG provisions. ${ }^{25}$

There are three main fields in which domestic law remedies could interfere with the CISG provisions on buyers' remedies in the case of non-conforming goods:

The first one is tortious remedies or-in continental, mostly German-speaking legal systems-quasi-contractual remedies under the Latin doctrine of culpa in contrahendo for

\footnotetext{
${ }^{21}$ Cf. Martin Karollus, UN-Kaufrecht: Anwendungsbereich, Holzhandelsusancen, Mängelrüge, JURISTISCHE BLÄTtER 321 (1999); Ulrich Magnus, Art. 39, para. 49, in JULIUS von STAUdINGERS KOMMENTAR ZUM BÜRGERLICHEN GesetZBuCh MIT EINFÜHRUNGSGESETZ UND NebENGESETZEN, WIENER UN-KAUfRECHT (CISG) (Staudinger ed., 13th rev. ed. 2005) [hereinafter STAUDinger]; Ulrich Magnus, Art. 39, para. 22, in KommentaR zUM UN-Kaufrecht (Heinrich Honsell ed., 1997); Christoph Benicke, Art. 39 CISG, para. 7, in MÜNCHENER KOMMENTAR ZUM HANDELSGESETZBUCH, supra note 7; Dirk Schüssler-Langeheine, Art. 39, para. 4, in ÜBEREINKOMMEN DER VEREINTEN NATIONEN ÜBER VERTRÄGE ÜBER DEN INTERNATIONALEN WARENKAUf (CISG) (Hans Th. Soergel \& Alexander Lüderitz eds., 13th ed. 2000); Ernst A. Kramer, Rechtzeitige Untersuchung und Mängelanzeige bei Sachmängeln nach Art. 38 und 39 UN-Kaufrecht-Eine Zwischenbilanz, in BEITRÄGE ZUM UNTERNEHMENSRECht, FeStSChrift Hans-Georg KopPENSTEINER 617, 628 (Ernst A. Kramer ed., 2001).

${ }^{22}$ See, e.g., Cour de Cassation, May 26, 1999, CISG-online 487 (five weeks); Cour d'appel de Versailles, Jan. 29, 1998, CISG-online 337 (six / eleven months); Cour d'appel de Colmar, Oct. 24, 2000, CISG-online 578 (two months).

${ }^{23}$ See Audiencia Provincial de Pontevedra, Oct. 3, 2002, CISG-online 1108.

${ }^{24}$ TeeVee Toons, Inc. v. Gerhard Schubert GmbH, S.D. NY, Aug. 22, 2006, CISG-online 1272.

${ }^{25}$ Cf. Sonja A. Kruisinga, (NoN-)CONFormity IN THE 1980 UN Convention ON CONTRACTS FoR the INTERNATIONAL SALE OF GOODS: A UNIFORM CONCEPT? 187-213 (2004).
} 
negligent misrepresentation of certain features of the goods at the time of the conclusion of the contract. ${ }^{26}$ The second field is tort recovery for purely economic loss caused by defective goods, as well as for property damages, especially in legal systems that recognize a tort claim for damage to the chattel itself. ${ }^{27}$ Finally, under certain legal systems, notwithstanding sales law remedies, in the case of non-conforming goods the buyer may rescind the whole contract on the basis of a mistake made when entering into the contract. ${ }^{28}$ All these domestic remedies may heavily interfere with the results reached under the CISG, for example, where the buyer is precluded from relying on the non-conformity of the goods because he/she did not inspect them, if damages were not within the contemplation of the parties, as required by the CISG, or if avoidance of the contract under the CISG is not possible because the breach does not amount to a fundamental one.

Until now, the question of whether the buyer may have resort to concurring domestic law remedies in all of these cases has not been thoroughly discussed either in case law or in scholarly writings. However, certain tendencies can be discerned from the existing debate.

Many representatives of the civil legal tradition favor a clear pro-convention approach to this issue. Even if domestic law provides, for example, for the possibility to rescind a sales contract on the grounds of unilateral mistake concerning the quality of the goods, it is almost unanimously held that this cannot apply if the sales contract is governed by the CISG. ${ }^{29}$ Likewise, it has been held that, although domestic German law allows a buyer to claim damages based in tort in the case of property damage to the chattel itself, this remedy is not available if the buyer is precluded from relying on its CISG remedies because it did not give timely notice of the non-conformity of the goods. ${ }^{30}$

\footnotetext{
${ }^{26}$ Cf. Joseph Lookofsky, In Dubio Pro Conventione? Some Thoughts About Opt-Outs, Computer Programs, and Preemption Under the 1980 Vienna Sales Convention (CISG), 13 DukE J. ComP. \& INT'L L. 263, 283 (2003); Markus Müller-Chen, Art. 45, para. 30, in Commentary on the UN Convention on tHe INTERnational Sale of Goods (CISG) (Peter Schlechtriem \& Ingeborg Schwenzer eds., 2d (Engl.) ed. 2005) [hereinafter SCHLECHTRIEM Commentary]; René Franz Henschel, The Conformity of Goods in InTernational Sales 74 (2005); Peter Huber, Some Introductory Remarks to the CISG, 6 InTERNATIONALES HANDELSRECHT 228, 234 (2006); Peter Schlechtriem, The Borderland of Tort and Contract-Opening a New Frontier?, 21 CoRNELL INT'L L.J. 467, at ПI.A. (1988) [hereinafter Schlechtriem, Tort]; Helen Elizabeth Hartnell, Rousing the Sleeping Dog: The Validity Exception to the Convention on Contracts for the International Sale of Goods, 18 YALE J. INT'L L. 1, at IV.A.4.b.

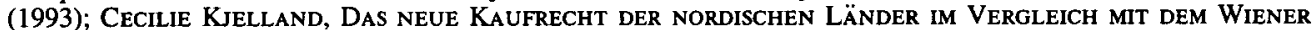
KAUFRECHT (CISG) UND DEM DEUTSCHEN KAUFRECHT 94 (1999).

${ }^{27}$ Cf. Markus Müller-Chen, Art. 45, para. 31, in SChlechtriem Commentary, supra note 26; John O. Honnold, UNiform LAW FOR INTERNATIONAL SALES UNDER THE 1980 UNITED NATIONS CONVENTION 73-76 (3d ed. 1999); HENSCHEL, supra note 26, at 75; Huber, supra note 26, at 233.

${ }^{28}$ Cf. Patrick C. Leyens, CISG and Mistake: Uniform Law vs. Domestic Law, The Interpretative Challenge of Mistake and the Validity Loophole, in REVIEW OF THE CONVENTION ON CONTRACTS FOR THE INTERNATIONAL SAlE of Goods (CISG) 2003-2004, at 3-51 (Pace Int'l L. Rev. ed., 2005); HonNold, supra note 27, at 261-63; Lookofsky, supra note 26, at 282-83; HENSCHEL, supra note 26, at 134-38; Huber, supra note 26, at 232; Schlechtriem, Tort, supra note 26, at II.A.; Christoph R. Heiz, Validity of Contracts Under the United Nations Convention on Contracts for the International Sale of Goods, April 11, 1980, and Swiss Contract Law, 20 VAND. J. TRANSNAT'L L. 639-63 (1987).

${ }^{29}$ Ingeborg Schwenzer, Art. 35, para. 45, in Schlechtriem CoMmentary, supra note 26; Markus Müller-Chen, Art. 45, para. 32, in SCHLECHTRIEM COMMENTARY, supra note 26. HensCHEL, supra note 26, at 138; Claude Witz, D. 2007 Pan., at 530, 533 (2007); Leyens, supra note 28, at 50; Huber, supra note 26, at 232.

${ }^{30}$ Oberlandesgericht Thüringen, 26 May 1998, CISG-online 513; cf. Rolf Herber, Zum Verhältnis von UNKaufrechtsübereinkommen und deliktischer Haftung, in FESTSCHRIFT FÜR PETER SCHLECHTRIEM ZUM 70. GeBURTSTAG 207, 218-20 (Ingeborg Schwenzer \& Günter Hager eds., 2003); Franco Ferrari, Art. 4, paras. 24, 46, in KOMMENTAR ZUM EINHEITLICHEN UN-KAUFRECHT-CISG-(Peter Schlechtriem \& Ingeborg Schwenzer eds., 4th (Ger.) ed. 2004); Ulrich Magnus, Art. 45, para. 43, in STAUDINGER, supra note 21; Dietrich Maskow, Art. 4, para. 3.1, in INTERNATIONALES KaUfrecht (Fritz Enderlein et al. eds., 1991); Sonja A. KRuisinga, supra note 25, at 212; Huber, supra note 26, at 233; but cf. Peter Schlechtriem, Art. 4, para. 23a, in SchleChTRIEm CommenTARY, supra note 26; id., Tort, supra note 26, at III.A.; JOSEPH LOOKOFSKY, UNDERSTANDING THE CISG IN THE USA 25-26, 71-73 (2d ed. 2004) [hereinafter CISG USA]; HERBERT BERNSTEIN \& JOSEPH LOOKOFSKY, UNDERSTANDING THE CISG IN EUROPE 71-73 (1997) [hereinafter CISG EUROPE].
} 
Quite a few Anglo-American scholars and courts seem to adopt a different stance. Although there is agreement that concurring state contractual claims, including claims for promissory estoppel, ${ }^{31}$ are preempted by the CISG, the prevailing opinion would appear to dictate that this is not the case as far as tort remedies are concerned. ${ }^{32}$ It is argued that "contractual and delictual remedies have coexisted in many jurisdictions for centuries, and a given State's ratification of the sales Convention does not imply its intention to merge contract with tort." 33

However, if one seeks to achieve the greatest level of uniformity, it cannot be left to individual states to apply their domestic laws, whether contractual or based in tort, alongside the CISG. Otherwise, the well-balanced CISG system of conformity of the goods and remedies could easily be made meaningless by national law. Therefore, the need to promote uniformity as it is laid down in CISG Article 7(1) must lead to the conclusion that, as the late John Honnold ${ }^{34}$ put it, the CISG displaces any domestic rules if the facts that invoke such rules are the same facts that invoke the Convention. In other words, wherever concurring domestic remedies are only concerned with the non-conformity of the goods-such as negligence in delivering non-conforming goods, negligent misrepresentation of the features of the goods, or mistake as to the features of the goods-such remedies must be preempted by the CISG. ${ }^{35}$ On the other hand, the CISG does not deal with fraud or safety requirements under product liability issues, thus leaving room for national concepts, such as fraudulent misrepresentation or product liability in case of property damage to property other than the goods sold. ${ }^{36}$

\section{SUMMARY}

In summary, it is not only due to the fact that the CISG does not address all issues that may arise in connection with an international sales contract that the intended uniformity and legal certainty in international trade is at risk in daily practice. Rather, the main danger emanates from the interpretation of the CISG provisions themselves by both judges and arbitrators whose approaches are still deeply rooted in their domestic preconceived views. Similarly precarious is allowing concurring domestic remedies to co-exist, which may undermine even the uncontroversial interpretation of CISG provisions in a core area.

What remedy can be suggested to prevent such a divergence? Several steps have already been taken to attenuate these risks. Thus, UNICITRAL itself has set up a system of national reporters to gather all relevant CISG court and arbitral decisions and to make them available in English (at least, in abstract form) to all member states. The UNICITRAL Digest has

\footnotetext{
${ }^{31}$ Cf. Geneva Pharmaceuticals Technology Corp. v. Barr Lab. Inc., S.D. NY, May 10, 2002, CISG-online 653; cf also LarRy A. DiMatteo et al., International Sales LaW, A Critical Analysis of CISG Jurisprudence 35-37 (2005); Franco Ferrari, Scope of Application: Articles 4-5, in DigesT AND BEYOND, supra note 10, at 96$113,108-09$.

${ }^{32}$ Cf. Lookofsky, supra note 26, at 285 n.111; Miami Valley Paper, LLC v. Lebbing Eng'g GmbH, Dist. Ct. OH, Oct. 10, 2006, CISG-online 1362; Hartnell, supra note 26, at IV.A.4.b.; PAtTric S. ATIYAH, The SAle of Goods 501-02 (9th ed. 1995); MARCo TORSEllo, COMmON FEATURES OF UNIFORM COMMERCIAL LAW CONVENTIONS 20 (2004); Johan Erauw, CISG Articles 66-70: The Risk of Loss and Passing It, 25 J.L. \& Com. 203, 208; but see Henry Mather, Choice of Law for International Sales Issues Not Resolved by the CISG, 20 J.L. \& Com. 155, 159 (2001); cf. for English law ANDREw BuRROWs, REMEDIES FOR TORTS AND BREACH OF CONTRACT 6-7 (3d ed. 2004).

${ }^{33}$ Lookofsky, supra note 26, at 286; cf. also CISG USA, supra note 30, at 71-73 and CISG EuROPE, supra note 30 , at $56-59$.

${ }^{34}$ See HoNNOLD, supra note 27 , at 67-68.

${ }^{35}$ Cf. HonNold, supra note 27, at 74, 262; Ingeborg Schwenzer, Art. 35, para. 47, in SChleChtriem CommentaRY, supra note 26.

${ }^{36}$ Cf. Ingeborg Schwenzer, Art. 35, para. 48, in SCHLECHTRIEM COMMENTARY, supra note 26; Huber, supra note 26 , at 232 .
} 
emerged from this project. In addition, there are several databases that make CISG case law from all over the world readily accessible; many of them are available in English. A group of leading CISG scholars from all over the world has come together to form the CISG Advisory Council, which releases opinions on highly controversial issues. ${ }^{37}$ But probably the most powerful incentive is the education of the younger generation. In this respect, special importance must be attributed to the Willem C. Vis International Arbitration Moot, ${ }^{38}$ now in its fourteenth year, which brings together more than a thousand students from almost 200 law schools in more than 50 different countries annually to discuss CISG problems. This new generation is able to appreciate the superiority of uniform sales law over the respective domestic solutions. I am confident that once this generation, trained in the CISG, enters the leading law firms, legal departments of international businesses, and courts and tribunals, uniform application and interpretation of the CISG will be achieved as a matter of course.

\footnotetext{
${ }^{37}$ So far, the CISG Advisory Council has published six opinions; $c f$. <http://www.cisg-online.ch/cisg/cisgac opinions.html>.

${ }^{38}$ At <http://cisgw3.law.pace.edu/vis.html>.
} 